\title{
EFFECT OF BASE ISOLATION IN MULTISTORIED RC IRREGULAR BUILDING USING TIME HISTORY ANALYSIS
}

\author{
Vinodkumar Parma ${ }^{1}$, G.S.Hiremath ${ }^{2}$ \\ ${ }^{1}$ Post - Graduate student, Department of Structural Engineering, Basaveshwar Engineering College, Bagalkot, \\ Karnataka, India \\ ${ }^{2}$ Asst.Prof. in Civil Engg, Department, Basaveshwar Engineering College, Bagalkot, Karnataka, India
}

\begin{abstract}
Base isolation (BI) is a technique that has been used around the world to protect the building structures from the damaging effects of earthquake. The installation of isolator in building at base level significantly increases the time period of the structure, which means it reduces the possibility of resonance of the structure giving rise to better seismic performance of the building. The study is performed to compare the effectiveness of base isolation in plan irregular and vertical irregular multi-storied RC frame building. For this study, 15 storied R.C frame building is considered and Time History analysis is carried out using ETABS 2013 software. The Lead Rubber Bearing (LRB) is designed as per UBC 97 code and the same was used for analysis of base isolation system. The results obtained from the analysis were time period and base shear. Time period for the base isolated structures are higher than that of the fixed base structure. Due to the presence of isolator, Base shear is significantly reduced in each direction (X and $Y$ direction) as compared to fixed base building. It has been found that when compared to plan irregular base isolated building the vertical irregular building gives better performance in high seismic prone area by using isolators at the base of the building.
\end{abstract}

Keywords: Base isolation, Lead rubber bearing, Time history analysis, Irregular building

\section{INTRODUCTION}

Earth quake is a shaking of the ground caused by movement of the tectonic plates relative to each other, both in direction and magnitude. A large part of the world people lives in area of seismic hazard at risk from earthquake of varying harshness and varying frequency of existence. Earthquake cause significant loss of life and destruction to property every year [9]. During past earthquake most of the irregular buildings collapsed due to the non-uniform distribution of the load compared to regular buildings.

Several seismic construction designs and technologies have been developed over the years in efforts to reduce the effect of earthquakes on structures, bridges and potentially susceptible contents. Seismic isolation is relatively recent and growing technology of this kind.

The isolation system decouples the structure from the horizontal components of the ground motion and reduces the possibility of resonance. This decoupling is achieved by increasing the flexibility of the system, together with appropriate damping by providing isolator at the basement level of the structure [9].

Table-1: List of some significant earthquake in India

\begin{tabular}{|l|l|l|}
\hline Date & Location & Magnitude \\
\hline 1819 Jun 16 & Kutch, Gujarat & 8.0 \\
\hline 1897 Jun 12 & Shillong plateau & 8.7 \\
\hline 1905 Apr 04 & Kangra, H.P & 8.0 \\
\hline 1934 Jan 15 & Bihar-Nepal border & 8.3 \\
\hline 1950 Aug 15 & ArunachalPradesh-China & 8.5 \\
\hline
\end{tabular}

\begin{tabular}{|l|l|l|}
\hline & border & \\
\hline 1991 Oct 20 & Utterkashi,UP Hills & 6.6 \\
\hline 1993 Sep 30 & Latur-Osmanabad, MH & 6.3 \\
\hline 1999 Mar 22 & Chamoli Dist.UP & 6.8 \\
\hline 2001 Jan 26 & Bhuj, Gujarat & 7.7 \\
\hline
\end{tabular}

The Indian subcontinent has a history of devastating earth quakes. The shaking memories of high intensity earthquakes of Bhuj and lathur are still alive in our minds. Even now there are frequent occurrences of earthquakes in the Kashmir and Himalayan region. The major reason for the high frequency and intensity of the earthquakes is that the Indian plate is driving into Asia at a rate of approximately $47 \mathrm{~mm} /$ year. Geographical data of India shows that almost $54 \%$ of the land is susceptible to earthquakes. A World Bank \& United Nations report shows estimates that around 200 million city occupiers in India will be exposed to storms and earthquakes by 2050 [8].

\subsection{Objectives of the Work}

To compare the response of the building such as Time period and Base shear for 15 storied RC plan and vertical irregular buildings with and without base isolation by considering the time history analysis using Bhuj earthquake data.

\section{MODELING AND ANALYSIS}

This study includes modeling and analysis of the models using standard ETABS software version 2013. Materials properties and section properties are defined and assigned. Reinforced concrete frame elements are modelled as beam 
and column element. Slab is modelled as area element. Modal analysis and time history analysis are performed on models.

\subsection{Description of Building}

In present work, 3D RC 15 storied plan irregular and vertical irregular buildings situated in zone $\mathrm{V}$, are taken for the study. Total 4 buildings have been considered for the comparison.

\subsubsection{Models Considered for Analysis}

\section{G+14 storied building}

Model 1A: Plan irregular RC building with fixed base.

Model 1B: Plan irregular RC building with Lead Rubber Bearing.

Model 2A: Vertical irregular RC building with fixed base.

Model 2B: Vertical irregular RC building with Lead Rubber Bearing.

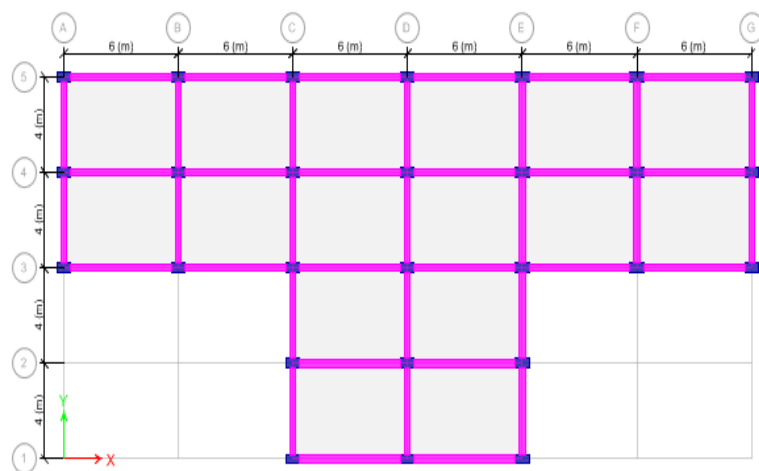

Fig-1: Plan view of Plan irregular building

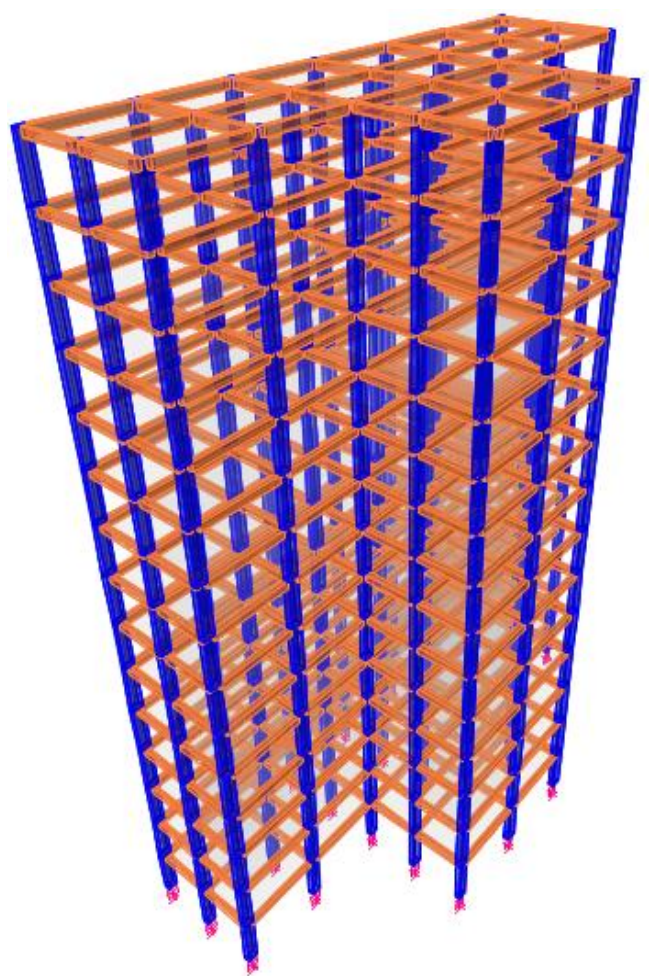

Fig-2: 3D view of plan irregular BI building

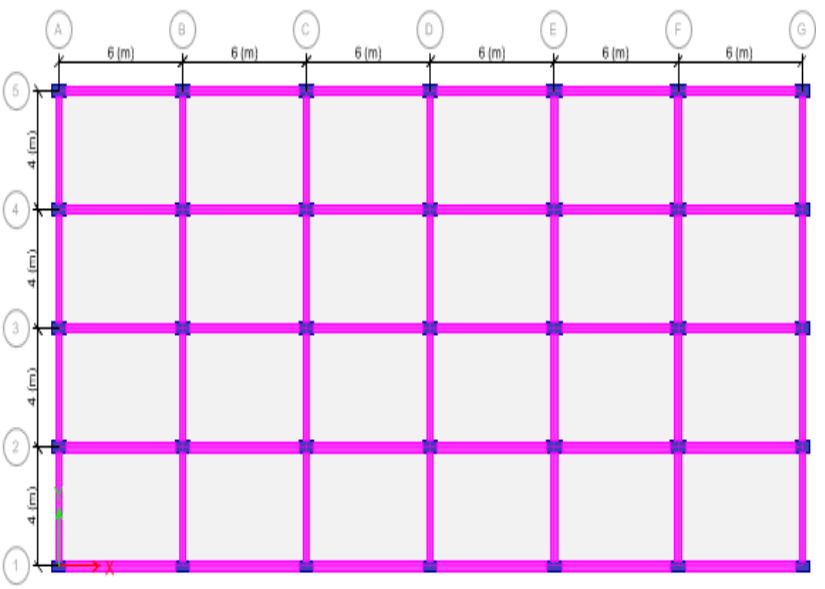

Fig-3: Plan view of vertical irregular building

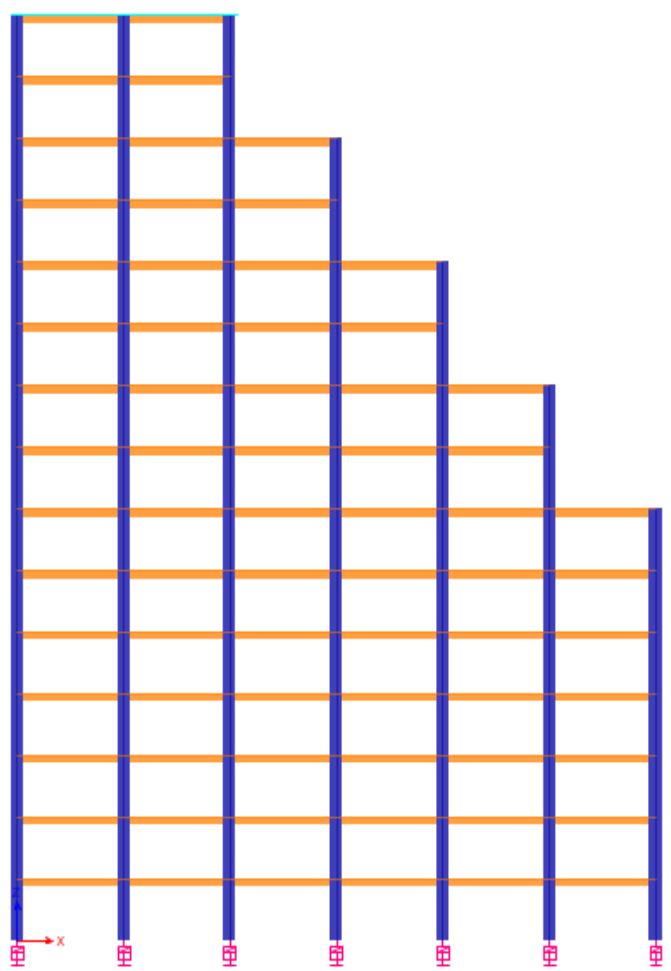

Fig-4: Elevation of vertical irregular BI Building

Table-2 Building details

\begin{tabular}{|l|l|}
\hline Grade of Concrete & M25 for beam \\
\hline Grade of Concrete & M30 for column \\
\hline Grade of Steel & Fe500 \\
\hline Story height & $3.2 \mathrm{~m}$ \\
\hline Beam size & $300 \times 450 \mathrm{~mm}$ \\
\hline Column size & $400 \times 700 \mathrm{~mm}$ \\
\hline Slab thickness & $150 \mathrm{~mm}$ \\
\hline Wall thickness & $230 \mathrm{~mm}$ \\
\hline Parapet height & $1 \mathrm{~m}$ \\
\hline Live load on the floor & $3 \mathrm{kN} / \mathrm{m}^{2}$ \\
\hline Live load on roof & $1.5 \mathrm{kN} / \mathrm{m}^{2}$ \\
\hline
\end{tabular}




\subsection{Properties of LRB used for Analysis}

By considering the maximum gravity service load coming on the column at the base of structure, the Lead Rubber Bearing has been designed.

Table-3: Isolator properties

\begin{tabular}{|l|l|l|}
\hline Properties & $\begin{array}{l}\text { Plan } \\
\text { irregular } \\
\text { building }\end{array}$ & $\begin{array}{l}\text { Vertical } \\
\text { irregular } \\
\text { building }\end{array}$ \\
\hline $\begin{array}{l}\text { Axial load on column } \\
(\mathrm{P}) \mathrm{kN}\end{array}$ & 7750 & 7810 \\
\hline $\begin{array}{l}\text { Eff. Vertical stiffness } \\
\left(\mathrm{k}_{\mathrm{v}}\right) \mathrm{kN} / \mathrm{m}\end{array}$ & 1660250.23 & 1673103.78 \\
\hline Damping $(\varepsilon)$ & 0.10 & 0.10 \\
\hline $\begin{array}{l}\text { Eff. Horizontal } \\
\text { Stiffness }\left(\mathrm{k}_{\mathrm{h}}\right) \mathrm{kN} / \mathrm{m}\end{array}$ & 4590.82 & 5030.07 \\
\hline $\begin{array}{l}\text { Pre yield stiffness } \\
\left(\mathrm{k}_{\mathrm{u}}\right) \mathrm{kN} / \mathrm{m}\end{array}$ & 38696.08 & 42398.49 \\
\hline PYSR $\left(\mathrm{K}_{\mathrm{d}} / \mathrm{K}_{\mathrm{u}}\right)$ & 0.10 & 0.10 \\
\hline $\begin{array}{l}\text { Yield force of lead } \\
\text { plug }\left(\mathrm{Q}_{\mathrm{d}}\right) \mathrm{kN}\end{array}$ & 149.30 & 163.59 \\
\hline
\end{tabular}

\section{RESULTS AND DISCUSSION}

In this study, the comparison of fixed and base isolated building is done. The totally four models are analyzed and the parameters like time period and base shear are compared using Bhuj earthquake data.

\subsection{Time Period}

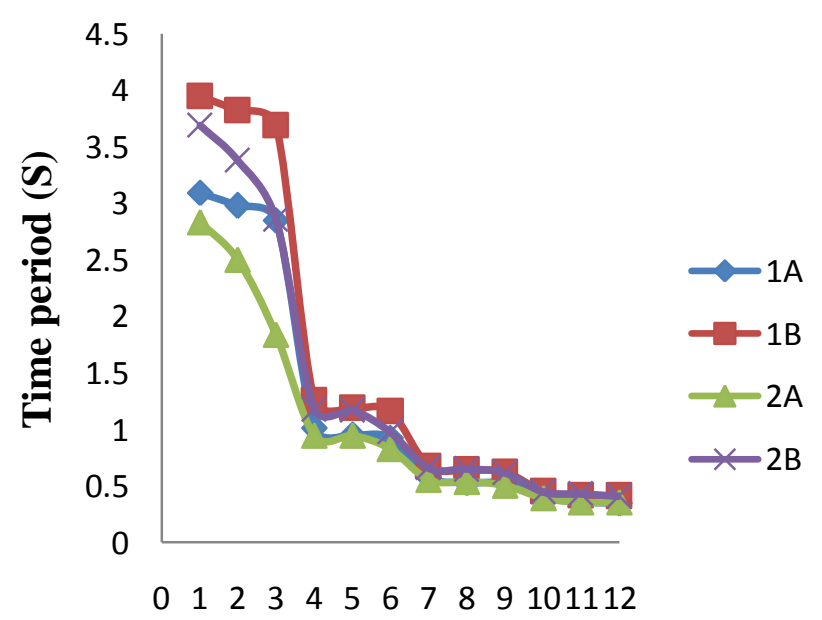

\section{Mode No.}

Fig-5: Time period for different models

From fig. 5 it is observed that, time period decreases with increase in mode number. As result of the increased flexibility of the system, time period of the structure is also increases.
Table-4: Time period for different models in $\mathrm{X}$ and $\mathrm{Y}$ direction

\begin{tabular}{|l|l|l|}
\hline \multirow{2}{*}{$\begin{array}{l}\text { Model } \\
\text { S }\end{array}$} & \multicolumn{2}{|l|}{ Time period $(\mathbf{S})$} \\
\cline { 2 - 3 } & X-X direction & Y-Y direction \\
\hline 1A & 2.97 & 3.09 \\
\hline 1B & 3.82 & 3.94 \\
\hline 2A & 2.49 & 2.83 \\
\hline 2B & 3.38 & 3.68 \\
\hline
\end{tabular}

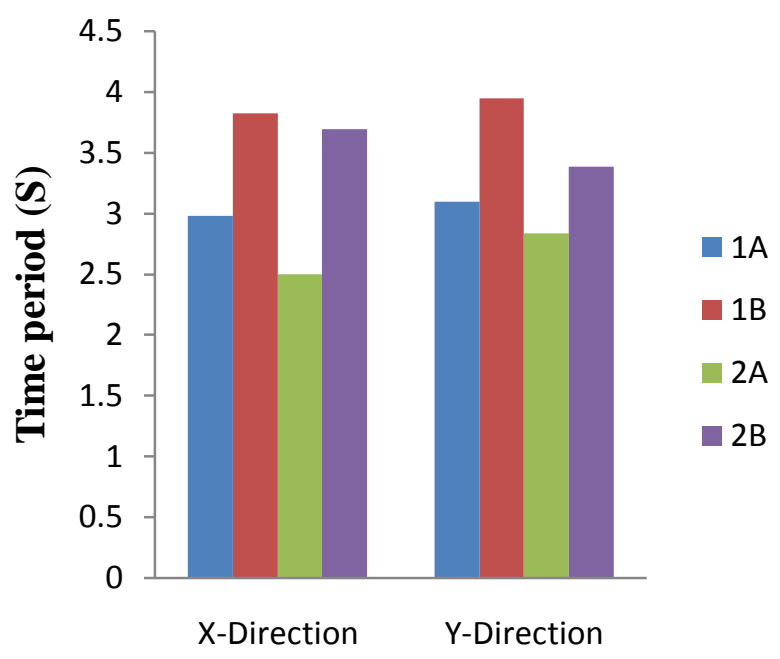

Fig-6: Mode period for different models along X and Y direction

From figure 6 it is absorbed that, time period in model $1 \mathrm{~B}$ is increased by $22 \%$ in $\mathrm{X}$ direction and $21 \%$ in $\mathrm{Y}$ direction compared to model 1A. Similarly in model $2 \mathrm{~B}$ is increased by $27 \%$ in $\mathrm{X}$ direction and $23 \%$ in $\mathrm{Y}$ direction compared to model $2 \mathrm{~A}$.

\subsection{Base Shear}

The table shows maximum base shear along $\mathrm{X}$ and $\mathrm{Y}$ direction.

Table-5: Maximum base shear $(\mathrm{kN})$ along $\mathrm{X}$ and $\mathrm{Y}$ direction for different models

\begin{tabular}{|l|l|l|}
\hline \multirow{2}{*}{ Models } & Base shear $(\mathbf{k N})$ \\
\cline { 2 - 3 } & X-direction & Y-direction \\
\hline 1A & 3629.20 & 2793.13 \\
\hline 1B & 1988.94 & 1921.50 \\
\hline 2A & 5739.24 & 3596.05 \\
\hline 2B & 2312.51 & 2362.89 \\
\hline
\end{tabular}




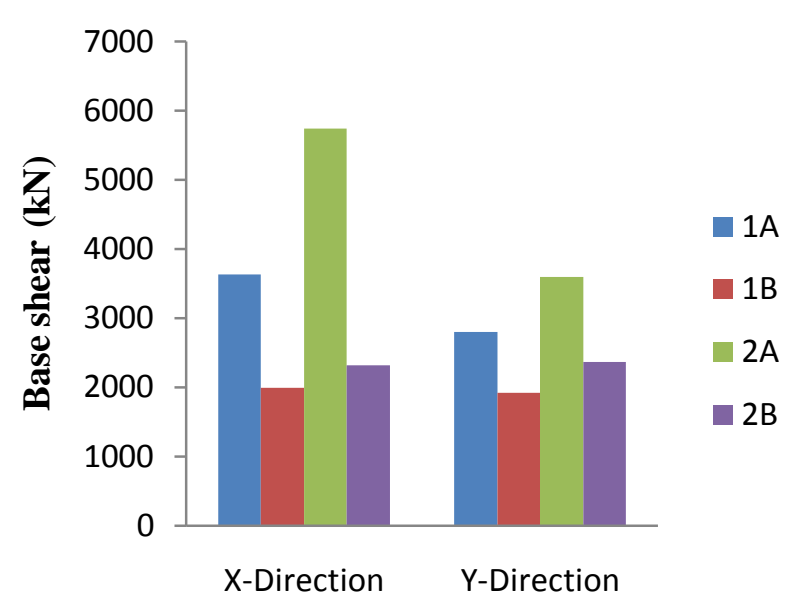

Fig-7: Base shear $(\mathrm{kN})$ along $\mathrm{X}$ and $\mathrm{Y}$-direction

From figure 7 is clear that, base shear in model $1 \mathrm{~B}$ is decreased by $45 \%$ in $\mathrm{X}$ direction and $31 \%$ in $\mathrm{Y}$ direction compared to model 1A. Similarly in model 2B is decreased by $60 \%$ in $\mathrm{X}$ direction and $34 \%$ in $\mathrm{Y}$ direction compared to model $2 \mathrm{~A}$.

\section{CONCLUSION}

$>$ By the analysis it is observed that base isolation increases the flexibility at the base level of the building.

$>$ Time period of the structure increases by the use of lead rubber bearing which helps in less transfer of lateral forces at the time of earthquake.

$>$ The increase in time period of the structure is found to be more in vertical irregular base isolated building compared to plan irregular base isolated building.

$>$ The base isolation has high efficiency in decreasing the base shear compared to fixed base building.

$>$ Reduction in base shear is more in vertical irregular base isolated building compared to plan irregular base isolated building.

$>$ From the study it shows that, the vertical irregular building gives better performance by the use of isolators at the base of the building as compared to plan irregular building at higher seismic prone area.

\section{REFERENCES}

[1]. A. Abrishambaf and G. Ozay (2010), "Effects of isolation damping and stiffness on the seismic behaviour of structures", ISBN: 978-960-474-251-6.

[2]. Athamnia Brahim and Ounis Abdelhafid (2011), "Effects of seismic isolation in the reduction of the seismic response of the structure", International Journal of Applied Engineering Research, Dindigul, Volume 2, No 2, 2011, ISSN 09764259.

[3]. C.Prabha and Basil Sabu (2014) "Study of Base Isolation in Multi-Storeyed Buildings" ISSN: 23471964 (Online) 2347-1875 (Print) Vol.2, Issue 8.

[4]. Farzad Naeim and James M. Kelly (1999), "Design of seismic isolated structure", John Wiley and Sons, inc.Newyork.
[5]. Fu Lin ZHOU, Zheng YANG, Wen Guang LIU And Ping TAN (2004), “ New Seismic Isolation System For Irregular Structure With The Largest Isolation Building Area In The World" 13th World Conference On Earthquake Engineering Vancouver, B.C., Canada, Paper No.2349.

[6]. Hussein Shakeri Soleimanloo (2012), "A Survey study on design procedure of Seismic Base Isolation Systems", J. Appl. Sci. Environ. Manage. Vol. 16 (4)299 -307.

[7]. IS 1893 (part 1):2002, Criteria for earthquake resistant design of structures.

[8]. IS 456:2000, Code of practice for plain and reinforced concrete.

[9]. Ivan Skinner, R., Trevor E. Kelly and Bill Robinson, W.H. (1993) A text book on Seismic Isolation for Designers and Structural Engineers, Robinson seismic limited, Holmes consulting group.

[10]. S.K. Sabu, H.S.Chore, S.B.Patil (2014), "Effectiveness of Lead Rubber Base Isolators, for seismic resistance of Buildings, supported on different soil stratas," ISSN (Online): 2347-2820, Volume -2.

[11]. Saiful Islam, A.B.M., Mohammed Jameel and Mohd Zamin Jumaat (2011), "Seismic isolation in buildings to be a practical reality',ISSN 2006-9790, Journal of Engineering and Technology Research Vol. 3(4), pp. 99-117.

[12]. Shirule P. A, Jagtap. L. P, Sonawane. K. R, Patil. T. D, Jadwanir. N and Sonar. S. K

(2012), "Time History Analysis of Base Isolated MultiStoryed Building", ISSN 0974-5904, Volume 05, No. 04, P.P. 809-816.

[13]. Syed Ahmed Kabeer K I and Sanjeev Kumar K.S (2014), "Comparison of Two Similar Buildings with and without Base Isolation", International Journal of Advance research, Ideas and Innovations in technology, volume 1, Issue 1.

[14]. T.K. Datta (2010), "Seismic Analysis of Structures", Indian Institute of Technology

Delhi, India.

[15]. Trevor E Kelly, S.E. (2001), "Design Guidelines on Base Isolation of Structures", Holmes consulting group, New Zealand.

[16]. W.F. Chen and Charles Scawthorn (2003), "Earthquake Engineering Handbook"

CRC press, Boca Raton London, New York, Washington.

\section{BIOGRAPHIES}

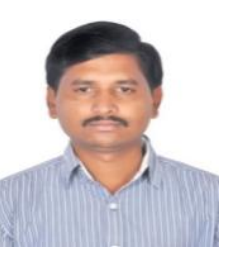

Vinodkumar Parma, pursuing postgraduation in Structural Engineering at Basaveshwar Engineering College, Bagalkot, Karnataka, India

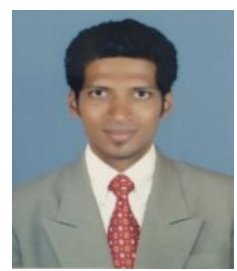

Asst. Prof. in Civil Engg. Dept., Basaveshwar Engineering College, Bagalkot, Karnataka, India 